\title{
Economic feasibility of cooling dry cows across the United States
}

\author{
F. C. Ferreira, ${ }^{*} \dagger$ R. S. Gennari, ${ }^{*}$ G. E. Dahl, ${ }^{*}$ and A. De Vries ${ }^{* 1}$ \\ *Department of Animal Sciences, University of Florida, Gainesville 32611 \\ †EMBRAPA Gado de Leite, Juiz de Fora, MG, Brazil 36038-330
}

\section{ABSTRACT}

Heat stress during the dry period reduces milk yield in the subsequent lactation of dairy cows. Our objectives were to quantify the economic losses due to heat stress if dry cows are not cooled and to evaluate the economic feasibility of dry cow cooling. We used weather data from the National Oceanic and Atmospheric Administration to calculate the number of heat stress days for each of the 50 US states. A heat stress day was declared when the daily average temperature-humidity index was $\geq 68$. The number of dairy cows in each state in 2015 was obtained from the USDA-National Agricultural Statistics Service. We assumed that $15 \%$ of the cows were dry at any time, a 60-d dry period, and a calving interval of $400 \mathrm{~d}$. Only cows in their second or greater parity $(65 \%)$ benefitted from cooling during the dry period of the previous parity. Milk yield decreased by $5 \mathrm{~kg}$ in the subsequent lactation $(340 \mathrm{~d})$ if the cow experienced heat stress during the dry period based on a review of the literature. The default marginal value of milk minus feed cost was $\$ 0.33 / \mathrm{kg}$ of milk. The investment analysis included purchases of fans and soakers and use of water and electricity. Investment in a dry cow barn was considered separately. The average US dairy cow would experience $96(26 \%)$ heat stress days during the year if not cooled and loses $447 \mathrm{~kg}$ of milk in the subsequent lactation if not cooled when dry. Annual losses would be $\$ 810$ million if dry cows were not cooled ( $\$ 87 /$ cow per yr). For the top 3 milk-producing states (California, Wisconsin, New York), and Florida and Texas, the average milk losses in the subsequent lactation were 522, 349, 387, 1,197, and $904 \mathrm{~kg}$, and reduced profit per cow per year would be $\$ 101, \$ 68$, $\$ 75, \$ 233$, and $\$ 176$, respectively. The average benefitcost ratio and payback periods of cooling dry cows in the United States were 3.15 and $0.27 \mathrm{yr}$ (dry cow barn already present) and 1.45 and $5.68 \mathrm{yr}$ (if investing in a dry cow barn) in the default scenario. To reach positive net present values, $6 \mathrm{~d}$ (barn is present) and $55 \mathrm{~d}$ (barn

Received June 6, 2016.

Accepted August 21, 2016.

${ }^{1}$ Corresponding author: devries@ufl.edu investment necessary) of heat stress annually were necessary (default assumptions). Other benefits of cooling, such as increased health and more productive offspring, were not considered. In conclusion, cooling of dry cows was profitable for $89 \%$ of the cows in the United States when building a new barn is required (under default assumptions) and very profitable when construction of a dry cow barn is not required (except for Alaska).

Key words: heat stress, temperature-humidity index, dry cow, economic feasibility

\section{INTRODUCTION}

Heat stress is a major factor affecting dairy cows across the United States. The effects of heat stress during the lactation on lactating cows have been extensively studied (e.g., West, 2003; Collier et al., 2006; De Rensis et al., 2015). St-Pierre et al. (2003) calculated that heat stress is responsible for annual losses of over $\$ 1$ billion in the dairy industry in the United States if lactating cows are not sufficiently cooled, mainly due to the negative effects on milk production, DMI, reproduction, and culling. Heat stress is the costliest problem that dairy farmers face during the summer (Baumgard and Rhoads, 2012). However, these studies did not include the losses associated with dry cows that experienced heat stress. Although many farmers cool their lactating cows during periods of heat stress, cooling of dry cows is often ignored.

The long-term consequences of heat stress during the dry period were first studied by Collier et al. (1982) and Thatcher et al. (1984) who showed the effects on calf birth weight and the seasonality of birth weight in Holstein calves. Wolfenson et al. (1988) observed negative effects on calf weight and milk production. More recent work at the University of Florida has further demonstrated the benefits of dry cow cooling on improved calf performance and cow health in the next lactation. Heat stress during the dry period results in impaired mammary growth and consequently leads to decreased milk production in the subsequent lactation (Tao and Dahl, 2013). Cows cooled with soakers and fans during the entire dry period of $46 \mathrm{~d}$ had greater milk production of 5 to $7.5 \mathrm{~kg} / \mathrm{d}$ in the subsequent lactation compared 
with those cows that were under shade only (do Amaral et al., 2009; Tao et al., 2011, 2012). When cows were cooled only during the last 2 wk before parturition, the increase in milk production in the subsequent lactation was $1.4 \mathrm{~kg} / \mathrm{d}$ (Urdaz et al., 2006). In all these studies, all cows were cooled during the lactation.

Other effects of heat stress during the dry period are also reported, such as decreased fertility in cows (Wiersma and Armstrong, 1988), decreased immunity and fertility (do Amaral et al., 2011; Thompson and Dahl, 2012), and reduced birth weights and growth rates in calves born out of cows that experienced heat stress when dry (Collier et al., 1982; do Amaral et al., 2011; Tao et al., 2012).

Given the negative and long-term consequences of heat stress during the dry period, cooling dry cows may have economic benefits. Typical cooling of dry cows requires investments in soakers and fans. In addition, a dry cow barn may have to be built if dry cows are housed outside, as is common in, for example, Florida. These costs are not dependent on the length of time that heat stress would be experienced. Other costs to cool dry cows depend on the length of time during the year when dry cows would experience heat stress, which varies by geographic location across the United States.

Dhuyvetter et al. (2000) and St-Pierre et al. (2003) provided economic analyses of the cooling of lactating cows. The available economic analyses of cooling dry cows are limited. Adin et al. (2009) calculated that the total cost of cooling a dry cow in Israel was equivalent to the net income from $80 \mathrm{~kg}$ more milk. In that study, cows that were cooled during the dry period produced $190 \mathrm{~kg}$ more milk in the first 90 DIM versus cows that were not cooled when dry. However, Adin et al. (2009) did not account for the increase in DMI by cows that produced more milk, nor did they include other factors such as investment in cooling technology and number of heat stress days. We did not find other economic feasibility analyses of cooling dry cows.

Therefore, our first objective was to quantify the economic losses from lost milk production across the United States if all dry cows would not be cooled. Our second objective was to provide an economic feasibility analysis of investments in soakers and fans as well as cooling barns for dry cows across the United States.

\section{MATERIALS AND METHODS}

\section{Weather Data}

One measure of heat stress is a temperature-humidity index (THI) above a threshold (West, 2003; Collier et al., 2006). We quantified heat stress across the United States by calculating the average THI per calendar day for each of the 50 states. We used daily data provided by the National Oceanic and Atmospheric Administration for the years 2007 to 2013. The data set contained weather data including average daily temperature $\left({ }^{\circ} \mathrm{F}\right)$ and dewpoint $\left({ }^{\circ} \mathrm{F}\right)$. We averaged the data from all available weather stations within each state. Relative humidity (RH) was calculated as follows (NOAA, 2015):

$$
\mathrm{RH}=\left\{\frac{[(173-0.1 \times \mathrm{T})+\text { dewpoint }]}{173+(0.9 \times \mathrm{T})}\right\}^{8},
$$

where $\mathrm{T}=$ average daily temperature $\left({ }^{\circ} \mathrm{F}\right)$. We calculated the THI according to the formula of Zimbelman et al. (2009):

$$
\mathrm{THI}=\mathrm{T}-[0.55-(0.55 \times \mathrm{RH}) \times(\mathrm{T}-58)] .
$$

We declared a heat stress day when average daily THI $\geq 68$ (Zimbelman et al., 2009). We calculated the number of heat stress days per state in each year and averaged those across the years.

\section{Milk Production and Number of Dry Cows}

We used data from USDA-NASS (2016) to obtain the total milk production and total number of dairy cows for each of the 50 states in the United States in 2015. We assumed that $15 \%$ of the total number of dairy cows were dry at any time during the year and the calving interval was $400 \mathrm{~d}$. We also assumed that only cows in their second or greater parity (65\%) benefitted from cooling during the dry period in the previous parity because we did not consider the benefits of cooling pregnant heifers during their later gestation period, although no evidence is present to indicate that they do not benefit. From this, we calculated the number of lactating cows that might benefit from cooling in the dry period.

\section{Milk Losses}

In Table 1, we summarized the results of 11 studies that documented the effects of heat stress during the dry period on milk loss in the subsequent lactation. Based on recent studies, we assumed a reduced milk production of $5 \mathrm{~kg} / \mathrm{d}$ for 340 lactating days in her subsequent parity if the cow experienced heat stress during the dry period. Further, we assumed that the decrease in milk yield in a state was proportional to the number of heat stress days for that state. For example, $70 \%$ of the dry cows are under heat stress during the year if not cooled in Florida. Thus, without cooling, we assumed a loss in 
Table 1. References, length of the preceding dry period, days of milk production measured in the subsequent lactation, and milk loss in the subsequent lactation of 11 studies that investigated the effect of dry cow heat stress on milk production in the subsequent lactation

\begin{tabular}{|c|c|c|c|}
\hline Reference & $\begin{array}{l}\text { Dry period } \\
\text { length (d) }\end{array}$ & $\begin{array}{l}\text { Milk production } \\
\text { measured in the } \\
\text { subsequent } \\
\text { lactation }(d)\end{array}$ & $\begin{array}{c}\text { Milk loss in } \\
\text { the subsequent } \\
\text { lactation }(\mathrm{kg} / \mathrm{d})\end{array}$ \\
\hline Collier et al. (1982) & 60 & 100 & 1.2 \\
\hline Collier et al. (1982) & 60 & $305^{1}$ & 2.6 \\
\hline Wolfenson et al. (1988) & 60 & 150 & 3.5 \\
\hline Avendaño-Reyes et al. (2006) & 60 & 100 & 2.6 \\
\hline Urdaz et al. (2006) & $28^{2}$ & 60 & 1.4 \\
\hline Adin et al. (2009) & 60 & 90 & 2.1 \\
\hline do Amaral et al. (2009) & 46 & 210 & 7.5 \\
\hline do Amaral et al. (2011) & 46 & 140 & 2.3 \\
\hline Tao et al. (2011) & 46 & 280 & 5 \\
\hline Tao et al. (2012) & 46 & 294 & 6.3 \\
\hline Thompson et al. (2014) & 46 & 280 & 3.8 \\
\hline
\end{tabular}

${ }^{1} 305$-d predicted yield adjusted for age, month of calving, and estimated relative producing ability.

${ }^{2}$ Cooling in the close-up period only.

milk production of $70 \% \times 5 \mathrm{~kg} / \mathrm{d}=3.5 \mathrm{~kg} / \mathrm{d}$ during the $340 \mathrm{~d}$ in their subsequent lactation for all second and greater parity cows. We only included losses in milk yield because those effects are better documented and easier to quantify than other effects such as reduced immunity, fertility, and calf performance.

\section{Economic Analysis}

Marginal Milk Income Minus Feed Costs. To calculate the extra milk income from cooling dry cows, we used as default a milk price of $\$ 0.44$ per $\mathrm{kg}$ of milk, based on the average of the all-US milk prices reported for 2010 to 2015 (Gould, 2016). We calculated increased milk income by multiplying the increased milk production from cooling dry cows by the milk price.

We assumed a cow consumes $0.71 \mathrm{Mcal}$ to produce 1 $\mathrm{kg}$ more milk. One kilogram of DM of a well-balanced TMR contains 1.7 Mcal (NRC, 2001). Therefore, we assumed that a cow consumed $0.4 \mathrm{~kg}$ of DM per $1 \mathrm{~kg}$ more milk. We assumed a cost of $\$ 0.28$ per $\mathrm{kg}$ of DMI (Rollin et al., 2015). Thus, the default milk revenue minus feed cost was $\$ 0.33$ per $\mathrm{kg}$ more milk as a result of dry cow cooling.

Cooling Investment Costs. Cooling costs of dry cows consisted of investment in a barn (if needed) and in fans and soakers. Cooling costs further included expenses for electricity and water during heat stress days. All costs were prorated across $20 \mathrm{yr}$, which is equal to the assumed lifespan of the barn (IRS, 2016).

The default investment costs for building a barn were assumed to be $\$ 2,500$ per stall (Kammel, 2015). This does not include the investment costs of fans and soakers. We assumed a residual value of $10 \%$ for the barn after $20 \mathrm{yr}$.
We assumed that the cooling system within the barn was composed of fans $(0.4 \mathrm{~kW}, 80 \mathrm{~cm}, 7 \mathrm{yr}$ lifetime $)$ and soakers including water pipe (5 yr lifetime). The cost of each fan was $\$ 700$ (Kammel, 2015). We assumed 5 dry cow stalls per fan based on the set up at the University of Florida Dairy Unit where most of the reviewed dry cow cooling studies have taken place. During the $20 \mathrm{yr}$ period, fans were purchased at the start of yr 1, 8, and 15 . We assumed a residual value of $10 \%$ and straight-line depreciation. Therefore, the remaining value per fan was $\$ 160$ in yr 20 . The cost of the soakers was based on Dhuyvetter et al. (2000), adjusted for inflation (DOL, 2015), and was assumed to be $\$ 8.19$ per stall. Soakers were purchased 4 times during the $20 \mathrm{yr}$ (years 1, 6, 11, and 16), and the remaining value was $\$ 0.80$ per stall.

Utilities. We calculated the fixed and variable costs of energy and water. Water and energy prices were taken from GRU (2015) and Dhuyvetter et al. (2000) corrected for inflation. Energy cost was divided in demand (fixed) and electricity (variable) charges, and they were set at $\$ 37$ and $\$ 1.62$ per fan per heat stress day, respectively. We assumed an energy efficiency of the fans of $0.75 \mathrm{~kW}$ and that a fan was used for all 24 $\mathrm{h}$ during a heat stress day. The cost of water was $\$ 0.42$ per $1,000 \mathrm{~L}$, and we assumed $56.8 \mathrm{~L}$ of water per stall per heat stress day to cool a dry cow.

Maintenance. We assumed stall maintenance cost of sand as $\$ 90 /$ dry cow stall per yr, when a new barn was built. The maintenance cost of fans and soakers was set at $\$ 15 /$ fan per year based on the setup at the University of Florida Dairy Unit.

Investment Feasibility Analysis. Cash flow during the 20-yr period was discounted at an annual discount rate of $5 \%$. We calculated the net present value 
(NPV) of investment in dry cow cooling per cow per year. In addition, the benefit-cost (BC) ratio was calculated by dividing the sum of the present value of 20 yr of revenues by the sum of the present value of 20 yr of costs. We calculated the payback period as the time to when the cumulative annual net revenue from milk sales minus feed cost equaled the total $20 \mathrm{yr}$ cost of the investment and utilities. We also calculated the internal rate of return (IRR), which is the discount rate when NPV equals $\$ 0$. The investment in cooling dry cows is worthwhile when NPV $>\$ 0, \mathrm{BC}$ ratio $>1$, payback period is short, and IRR $>$ annual discount rate (Higgins, 2001). Separate analyses were carried out for investments with and without building a barn.

We performed breakeven analyses for milk price, increase in milk production in the subsequent lactation, and barn investment cost per dry cow stall, for a payback period of $3 \mathrm{yr}$ for the top 3 states with the most dairy cows (California, Wisconsin, New York), as well as Florida and Texas, which are among the top 25 states for number of dairy cows and have a high number of heat stress days per year. For each variable that we changed, we kept the other variables at their default values (i.e., $\$ 0.44 / \mathrm{kg}$ milk price, $5 \mathrm{~kg} / \mathrm{d}$ increase in milk production in the subsequent lactation, $\$ 2,500 /$ stall barn investment cost).

We also varied milk price $(\$ 0.34, \$ 0.44$, and $\$ 0.54$ per $\mathrm{kg}$ of milk), potential increase in milk production in the subsequent lactation $(1,3$, and $5 \mathrm{~kg} / \mathrm{d})$, and investment costs per dry cow stall $(\$ 1,500, \$ 2,500$, and $\$ 3,500)$ to determine their effect on the NPV per cow per year when the number of heat stress days was varied from 0 to 360 . Again, one variable at a time was changed with all others at their default values as described above.

\section{RESULTS}

\section{Heat Stress and Milk Losses Without Cooling}

The USDA-NASS (2016) reported 9,322,400 dairy cows present in the United States in 2015. Of these, dry cows $(15 \%)$ were assumed to be $1,398,360$. These numbers have not changed much in the last decade. The numbers of dry and milking cows in the top 25 US states with the most dairy cows in 2013 are shown in Figure 1. Collectively, these 25 states had 8,805,000 (94.4\%) dairy cows in 2015. With the exception of California, which is responsible for $19.6 \%$ of the milk produced in the United States (USDA-NASS, 2016), the other 4 major milk-producing states are in the cooler northern part of the United States. Significant milk producing states such as Texas, New Mexico, Arizona, Florida, and Georgia, that together produced $13.2 \%$ of the total
US milk production, are in regions with a large number of heat stress days per year.

Figure 2 shows the number of heat stress days and the milk lost per cow in the subsequent lactation if dry cows are not cooled for the 25 states with the largest number of dairy cows. Based on the weighted average of the number of cows across the 50 states and the number of heat stress days in each state, an average US dairy cow is under heat stress $96 \mathrm{~d}$ (26\%) during the year. On average, $70 \%$ of the cows in Florida would experience heat stress during their dry periods if not cooled. In cooler northern states such as Washington and Maine, $12 \%$ of the dry cows still would experience heat stress if not cooled. In 23 out of 50 states, at least $30 \%$ of the dry cows would experience heat stress during the year. In the top 25 states with the greatest number of dairy cows (Figure 1), 26\% of the dry cows (weighted average) would experience heat stress, and in California $31 \%$ of the dry cows experience heat stress if not cooled.

Each day of heat stress during the year equates to $4.66 \mathrm{~kg}$ lower milk yield in the subsequent lactation. An average US dairy cow would lose $447 \mathrm{~kg}$ of milk in the subsequent lactation if not cooled when dry. This assumes first parity cows have no milk losses. Of the top 25 states with the most dairy cows, the weighted average loss is $441 \mathrm{~kg}$ in the subsequent lactation. For the top 3 states with most dairy cows (California, Wisconsin, New York), Florida and Texas, the average milk losses in the subsequent lactation were 522, 349, 387, 1,197 , and $904 \mathrm{~kg}$. Per average cow (including first parity cows), these values are 339, 227, 251, 778, and 587 $\mathrm{kg}$, respectively.

Weighted by the number of cows in each state, annual losses would be $\$ 810$ million if dry cows were not cooled (\$87/cow per year) using the default milk sales minus feed cost of $\$ 0.33 / \mathrm{kg}$ of milk. In California, the total economic losses if dry cows are not cooled are $\$ 181$ million per year. For California, Wisconsin, New York, Florida, and Texas, the average annual losses would be $\$ 101, \$ 68, \$ 75, \$ 233$, and $\$ 176 /$ cow per yr, respectively. The weighted annual loss is $\$ 162$ million if we assumed that heat stress during the full dry period decreased milk production by only $1 \mathrm{~kg} / \mathrm{d}$ in the subsequent lactation instead of $5 \mathrm{~kg} / \mathrm{d}$. When the milk price is reduced from $\$ 0.44$ to $\$ 0.34$ per $\mathrm{kg}$, total weighted annual losses in the United States would be $\$ 563$ million without dry cow cooling.

\section{Cooling Investment Analysis}

An example of the economic feasibility analysis of cooling dry cows in Florida is shown in Table 2. With investment in the barn, the NPV per cow per year was 


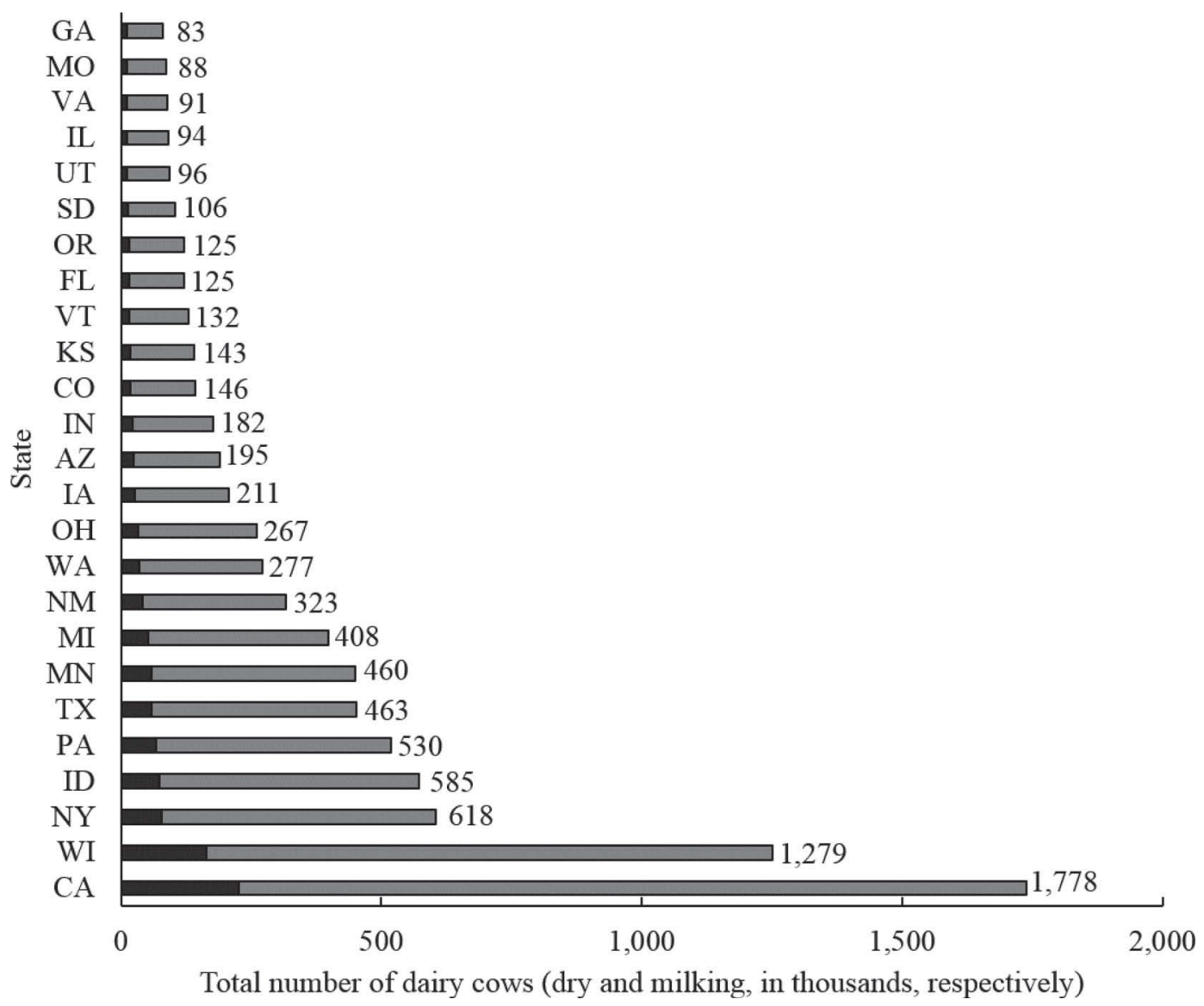

Figure 1. Total number of dairy cows in the top 25 states with the most dairy cows in 2015 (dry cows in dark gray, lactating cows in light gray). Source: USDA-NASS (2016). We assumed $15 \%$ of all cows were dry.

$\$ 111$, the $\mathrm{BC}$ ratio was 2.34 , and the payback period was 1.87 yr. Under these conditions, the IRR was $53 \%$. If only fans and soakers need to be purchased, those values would be $\$ 139,3.47,0.10 \mathrm{yr}$, and $1,017 \%$, respectively. For California, the results were $\$ 31,1.58$, $4.72 \mathrm{yr}$, and $20 \%$ when investment in the barn was necessary and $\$ 58,3.22,0.23 \mathrm{yr}$, and $440 \%$ without the barn investment, respectively.

Considering the weighted average number of heat stress days in the United States (96) and the default assumptions, the NPV, BC ratio, payback period, and IRR would be $\$ 22,1.45,5.67 \mathrm{yr}$, and $16 \%$, respectively (including building a dry cow barn). If the dry cow barn is already present, the values would be $\$ 50,3.15$, $0.27 \mathrm{yr}$, and $376 \%$. To reach an NPV $>\$ 0$, a minimum number of heat stress days of 6 and $9 \mathrm{~d}$ are necessary when a barn is not built when milk prices are $\$ 0.44$ and $\$ 0.34$, respectively. If investment in the barn is included, the minimum number of heat stress days would be 55 and 81 to reach a positive NPV, respectively. Of all US dairy cows, $89 \%$ are in states with at least 55 heat stress days per year. The only states in the top 25 with fewer than $55 \mathrm{~d}$ of heat stress per year are Washington, Oregon, and Idaho (43, 47, and $52 \mathrm{~d}$ of heat stress, respectively).

Assuming the default assumption for depreciation of barn, fans, and soakers, the NPV can be calculated as follows:

$$
\begin{gathered}
\text { NPV }(\$ \text { per cow per yr })=(-0.0075 \\
\times \text { barn cost per stall }-0.0935 \\
\times \text { barn maintenance per dry cow per yr }) \\
+(-0.0032 \times \text { cost per fan }-0.9721) \\
-(0.0216 \times \text { cost of soakers per stall }) \\
+(\text { number of heat stress days } \times\{-0.012 \\
\quad+[\text { kg increase in milk per day } \\
\times(0.344 \times \text { price per kg milk }-0.138 \\
\quad \times \text { price per kg of DM })]\}) .
\end{gathered}
$$


For example, the NPV per cow per year equals $\$ 35$ when barn cost per stall is $\$ 2,500$, barn maintenance per dry cow per yr is $\$ 90$, cost per fan is $\$ 700$, cost of soakers per stall is $\$ 8.19$, the number of heat stress days is 90 , increase in milk is $5 \mathrm{~kg} / \mathrm{d}$, price of milk is $\$ 0.54$ / $\mathrm{kg}$, and price of DM is $\$ 0.28 / \mathrm{kg}$ (Figure 3). When the barn cost is $\$ 0$, the barn maintenance is also $\$ 0$, so the NPV per cow per year is $\$ 62$.

Figures 3 and 4 show the results of the sensitivity analysis for variations in milk price, reduction in milk yield in the subsequent lactation, and barn investment cost per dry cow stall. The number of heat stress days per year is varied from 0 to 360 .

Figure 3 includes the barn investment cost. In 6 of the 7 scenarios shown, the number of heat stress days varied from 42 to 94 to create a positive NPV. This shows that cooling of dry cows including barn investment costs is profitable in most states in the United States. In Florida, with its $257 \mathrm{~d}$ of heat stress, the NPV was $\$ 119 /$ cow per yr when milk price was $\$ 0.44$ / $\mathrm{kg}$ and barn investment cost was low $(\$ 1,500)$. When the loss in milk production was assumed to be only 1 $\mathrm{kg}$ at a milk price of $\$ 0.44 / \mathrm{kg}$ and a barn investment cost of $\$ 2,500$, more than 305 heat stress days were necessary to reach a positive NPV. A combination of the higher milk price of $\$ 0.54 / \mathrm{kg}$, milk loss of $5 \mathrm{~kg} / \mathrm{d}$, and a barn investment cost of $\$ 2,500 /$ stall resulted in the greatest NPV of cooling dry cows. In this scenario, the NPV became positive with 42 heat stress days per year. Figure 4 does not include the barn investment cost, but only investment in fans and soakers. For all 5 scenarios, the NPV became positive between 5 and 35 heat stress days per year.

Table 3 shows the results of the breakeven analyses for the top 3 states with the greatest number of dairy cows in United States as well as Florida and Texas, assuming a payback period of $3 \mathrm{yr}$. When the barn investment cost was included, the results were more sensitive to the number of heat stress days. In Florida, the investment can be recovered in $3 \mathrm{yr}$ even if the increase in milk production is $3.3 \mathrm{~kg} / \mathrm{d}$, or the milk price is as low as $\$ 0.33 / \mathrm{kg}$ or the barn investment cost

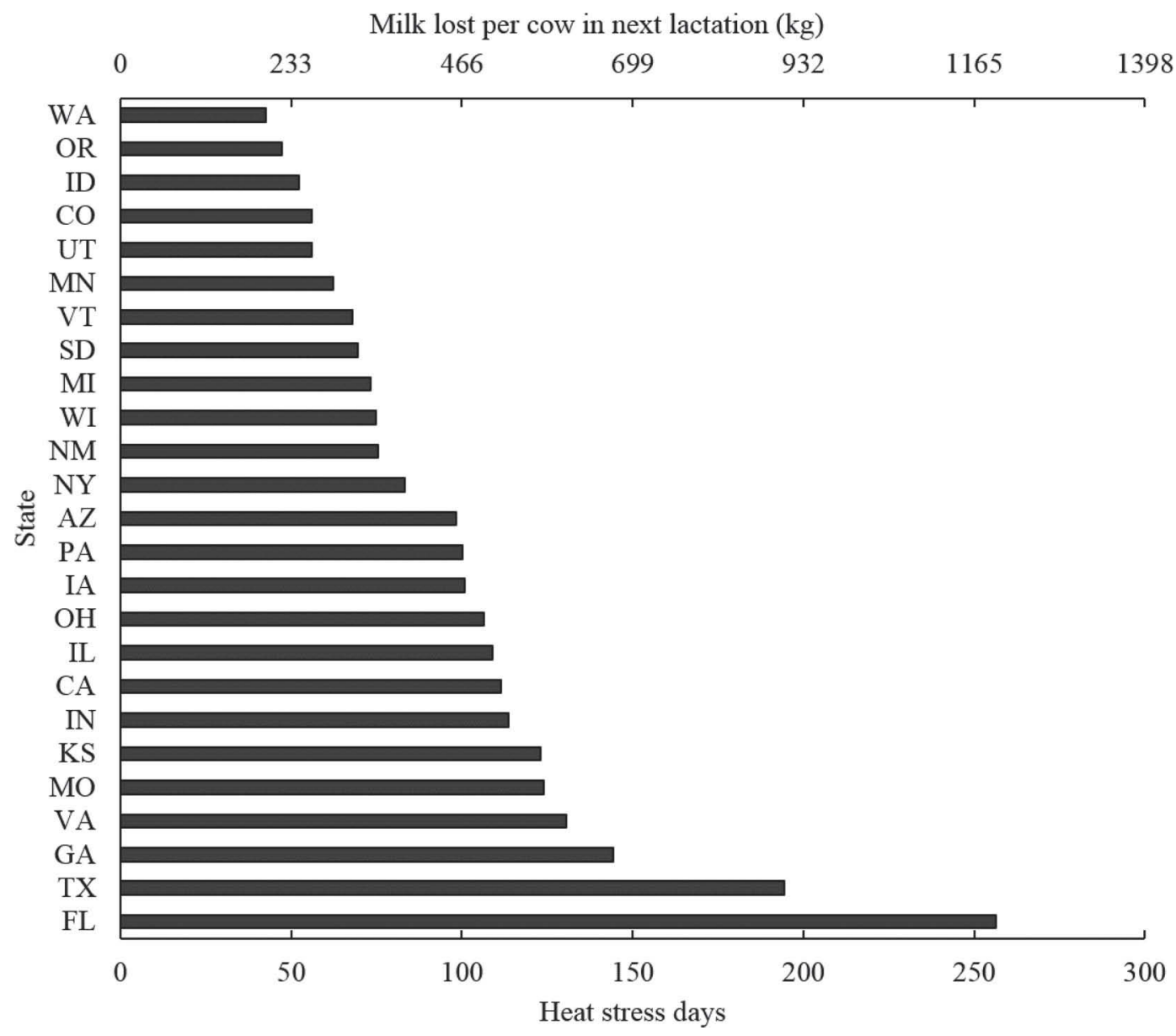

Figure 2. Milk lost per cow in the subsequent lactation $(340 \mathrm{~d})$ and days under heat stress for the top 25 states with the most dairy cows. We assumed an average loss of $4.66 \mathrm{~kg}$ per $340 \mathrm{~d}$ for each day of heat stress. 
Table 2. Economic feasibility analysis of cooling dry cows in Florida for a 100-cow herd

\begin{tabular}{|c|c|}
\hline Item & Value \\
\hline Number of lactating cows at any time during the year & 85 \\
\hline Number of dry cows at any time during the year & 15 \\
\hline Days with heat stress (average THI >68) during the year ${ }^{1}(\%)$ & $257(70 \%)$ \\
\hline Lactating days with benefit from cooling in subsequent lactation & 340 \\
\hline Milk loss in subsequent lactation when full time heat stress $(\mathrm{kg} / \mathrm{d})$ & 5 \\
\hline Cows in second and greater parity $(\%)$ & 65 \\
\hline Milk price $(\$ / \mathrm{kg})$ & 0.44 \\
\hline $\mathrm{kg}$ of DMI per $\mathrm{kg}$ more milk produced & 0.4 \\
\hline Feed price $(\$ / \mathrm{kg}$ of $\mathrm{DM})$ & 0.28 \\
\hline Number of dry stalls per fan & 5 \\
\hline Investment cost of a fan $(\$ /$ fan $)$ & 700 \\
\hline Lifetime of a fan (yr) & 7 \\
\hline Maintenance cost of a fan ( $\$ /$ fan per yr) & 15 \\
\hline Electrical demand charge ( $\$ /$ fan per yr) & 37 \\
\hline Electricity charge $(\$ / \mathrm{kWh})$ & 0.06 \\
\hline Power of a fan's motor $(\mathrm{kW})$ & 0.4 \\
\hline Energy efficiency of fans $(\mathrm{kW})$ & 0.75 \\
\hline Hours fan is used per heat stress day & 24 \\
\hline Investment costs of soaker line (\$/dry stall) & 8.19 \\
\hline Lifetime of a soaker line (yr) & 5 \\
\hline Soaker water usage (L/dry stall per heat stress day) & 56.8 \\
\hline Cost of water $(\$ / 1,000 \mathrm{~L})$ & 0.42 \\
\hline Investment cost of dry cow barn ( $\$$ dry cow stall) & 2,500 \\
\hline Lifetime of dry cow barn (yr) & 20 \\
\hline Barn maintenance, sand ( $\$$ /dry cow stall per yr) & 90 \\
\hline Present value of milk sales minus feed cost $(\$ /$ cow per heat stress day) & 0.56 \\
\hline Present value of barn investment + maintenance $(\$ /$ cow per yr $)$ & 27.16 \\
\hline Present value of soakers, fans investment + maintenance $(\$ /$ cow per yr) & 3.38 \\
\hline Present value of water and electricity use ( $\$ /$ cow per heat stress day) & 0.012 \\
\hline \multicolumn{2}{|l|}{ Including costs of fans, soakers, and barn investment } \\
\hline Net present value $(\$ /$ cow per yr $)$ & 111 \\
\hline Benefit:cost ratio & 2.34 \\
\hline Payback period of initial investments $(\mathrm{yr})$ & 1.87 \\
\hline Internal rate of return $(\%)$ & 53 \\
\hline \multicolumn{2}{|l|}{ Including costs of fans, soakers only } \\
\hline Net present value $(\$ /$ cow per yr) & 139 \\
\hline Benefit:cost ratio & 3.47 \\
\hline Payback period of initial investments (yr) & 0.10 \\
\hline Internal rate of return $(\%)$ & 1,017 \\
\hline
\end{tabular}

${ }^{1}$ THI $=$ temperature-humidity index.

is as high as $\$ 4,106$ per dry cow stall. However, when the barn investment cost was not included, dairy farmers in Florida would recover their investments in fans and soakers in 3 yr with milk prices as low as $\$ 0.13$ / $\mathrm{kg}$ (\$0.02 milk sales minus feed cost per $\mathrm{kg}$ of milk). A small increase in milk production in the subsequent lactation would be enough to pay the investment of cooling dry cows in $3 \mathrm{yr}$ in these 5 states if investment in the dry cow cooling barn is not required.

\section{DISCUSSION}

Our objectives were to quantify the economic losses from milk not produced across the United States if dry cows experienced heat stress during their dry period, and to provide an economic feasibility analysis of investments in soakers and fans as well as cooling barns for dry cows. The results showed a loss of $\$ 810$ million per year in the United States from lost milk production alone if dry cows were not cooled. It is not known how many dry cows actually experience heat stress as a result of a lack of cooling during periods of heat stress. Therefore, the opportunity value of further cooling dry cows is likely less than $\$ 810$ million annually.

\section{Heat Stress Assumptions}

We assumed that cows were either heat stressed every day of their dry period or did not experience any heat stress in their dry period. In most of the reviewed literature, cows experienced heat stress every day but not $24 \mathrm{~h} / \mathrm{d}$ because nights were cool. In practice, cows might experience heat stress on some days and not others. Urdaz et al. (2006) reported increase in milk production in the subsequent lactation for cows that were cooled only in the last $28 \mathrm{~d}$ of their dry period. It 
is not known if cooling during the entire dry period is necessary to obtain the benefits of cooling dry cows in the subsequent lactation.

The effects of cooling dry cows on milk production in the subsequent lactation, as reported in the literature review, were observed when lactating cows were not experiencing heat stress. It is not known what the effect of dry cow cooling is when the cow experiences some heat stress in the subsequent lactation, such as cows housed outdoors during summers without adequate access to heat abatement. We can expect that the majority if not all of the subsequent milk production occurs when the cow does not experience heat stress, however, either because she is actively cooled or because milk production happens in the cooler time of the year when no heat abatement is necessary anyway.

We used the average THI $\geq 68$ to describe either the presence of absence of heat stress (Zimbelman et al., 2009). This measure was developed for lactating cows and ignores the severity of heat stress. Although the dry cow produces less metabolic heat than a lactating cow and has a higher heat dissipation capacity, her endocrine system is more sensitive to moderate heat stress (Collier et al., 1982). Heat stress can reduce the concentrations of plasma thyroxin and placental estrogen, leading to an impairment in the growth and postpartum function of maternal tissues (Collier et al., 1982). A THI $\geq 68$ might therefore be a realistic indication of heat stress for the dry cow. In addition, the dry cow is likely to not be under shade and thus more exposed to solar radiation. In this case, the actual black globe heat load the dry cow experiences might be more severe than a THI of 68 .

Jordan (2003) stated that it would be important to measure the duration and intensity of heat stress to understand the full effect on cow performance. We ignored the heat load in a day, for example, as measured by the number of hours per day the THI was above a threshold (THI load) or under the temperature of $21^{\circ} \mathrm{C}$, conditions that help cows alleviate heat stress through dissipation of heat load gained previously (Scott et al., 1983; Igono et al., 1992). Other measures of a heat stress could change the number of heat stress days across the United States.

A preferred measure of heat stress is rectal temperature (Kadzere et al., 2002). A strong and positive

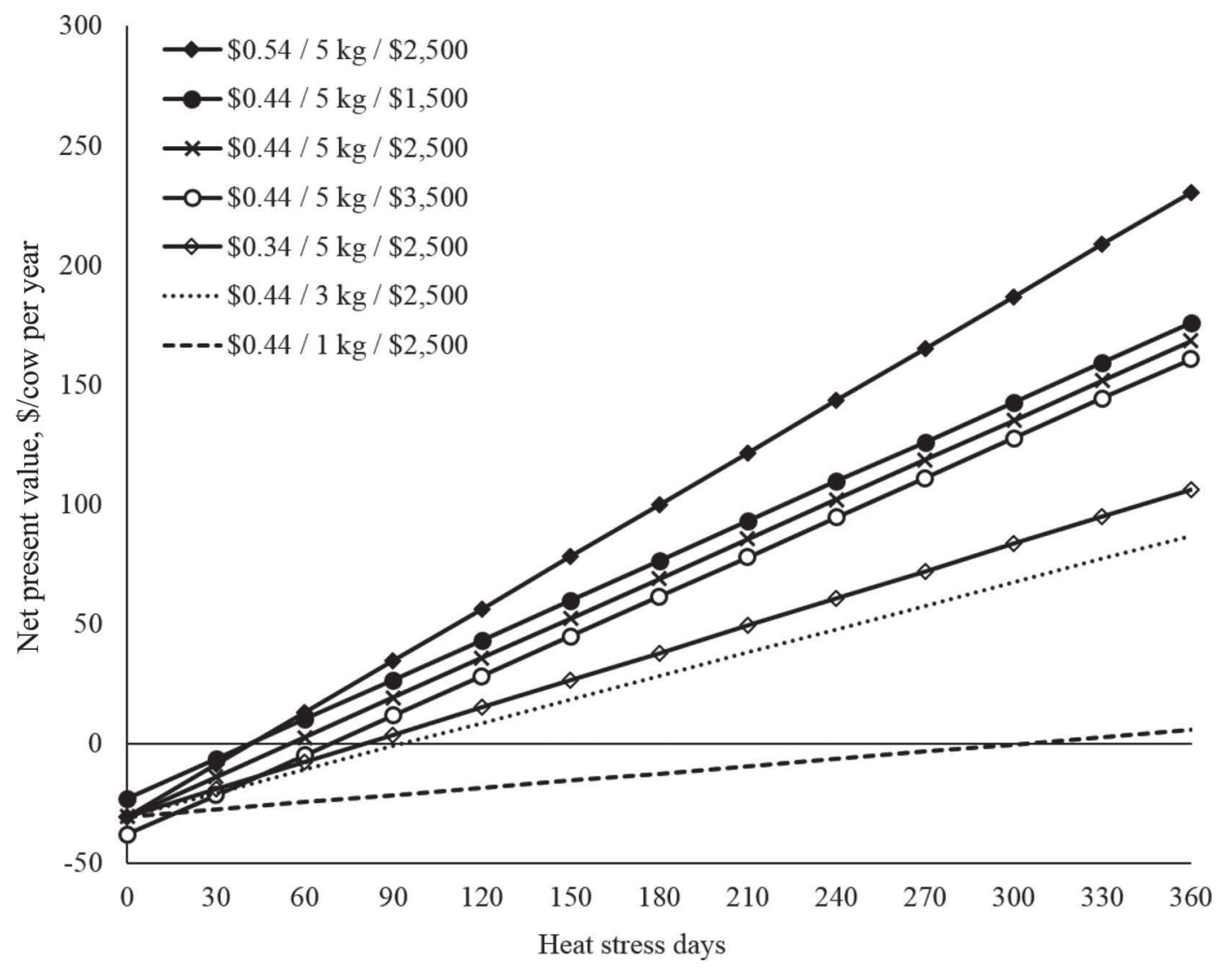

Figure 3. Net present value per cow per year for 0 to $360 \mathrm{~d}$ of heat stress per year. The costs of fans and soakers and barn investment costs were included. Milk prices $(\$ / \mathrm{kg}): 0.34,0.44$, and 0.54 . Increase in milk yield (kg/d): 1,3 , and 5 . Barn investment cost (\$/dry cow stall): 1,500 , 2,500 , and 3,500 . 
Table 3. Breakeven analysis for milk increase in subsequent lactation, milk price, and the barn investment cost, to obtain a payback period of 3 yr for the 3 states with the most dairy cows (California, Wisconsin, New York) and Florida and Texas ${ }^{1}$

\begin{tabular}{|c|c|c|c|c|c|}
\hline \multirow[b]{2}{*}{ State } & \multicolumn{3}{|c|}{ Barn + fans + soakers } & \multicolumn{2}{|c|}{ Fans + soakers only } \\
\hline & $\begin{array}{l}\text { Milk increase } \\
(\mathrm{kg} / \text { cow per d) }\end{array}$ & $\begin{array}{l}\text { Milk price } \\
(\$ / \mathrm{kg})\end{array}$ & $\begin{array}{c}\text { Barn investment cost } \\
(\$ / \text { dry cow stall })\end{array}$ & $\begin{array}{l}\text { Milk increase } \\
(\mathrm{kg} / \text { cow per } \mathrm{d})\end{array}$ & $\begin{array}{l}\text { Milk price } \\
(\$ / \mathrm{kg})\end{array}$ \\
\hline $\mathrm{CA}$ & 7.37 & 0.60 & 1,536 & 0.55 & 0.15 \\
\hline WI & 10.96 & 0.83 & 880 & 0.77 & 0.16 \\
\hline NY & 9.91 & 0.76 & 1,022 & 0.71 & 0.16 \\
\hline FL & 3.28 & 0.33 & 4,106 & 0.30 & 0.13 \\
\hline
\end{tabular}

${ }^{1}$ Default assumptions: $\$ 2,500$ barn investment cost per dry cow stall, $\$ 0.44 / \mathrm{kg}$ milk price, $5 \mathrm{~kg} / \mathrm{d}$ reduction in milk yield in the subsequent lactation if dry cows were not cooled. States and number of heat stress days: CA (112), WI (75), NY (83), FL (257), and TX (194). Variables were varied one at a time with the other variables set at their default values.

relationship is present between rectal temperature of dry cows in the afternoon and milk production in the subsequent lactation (Tao and Dahl, 2013). Under normal management, complete abatement of heat stress is unlikely, but active cooling could help decrease body temperature (Tao and Dahl, 2013).

We also assumed that the $15 \%$ of the herd is dry throughout the year, regardless of the season. Signifi- cant seasonality in reproductive performance exists in the Southeastern United States (al-Katanani et al., 1999; Oseni et al., 2003; De Vries and Risco, 2005). Consequently, the calving pattern results in a seasonal dry pattern. More cows are dry in the warmer season of the year than the cooler season to encourage fall calving (Du, 2013), which increases the estimated total loss of milk not produced if cows are not cooled.

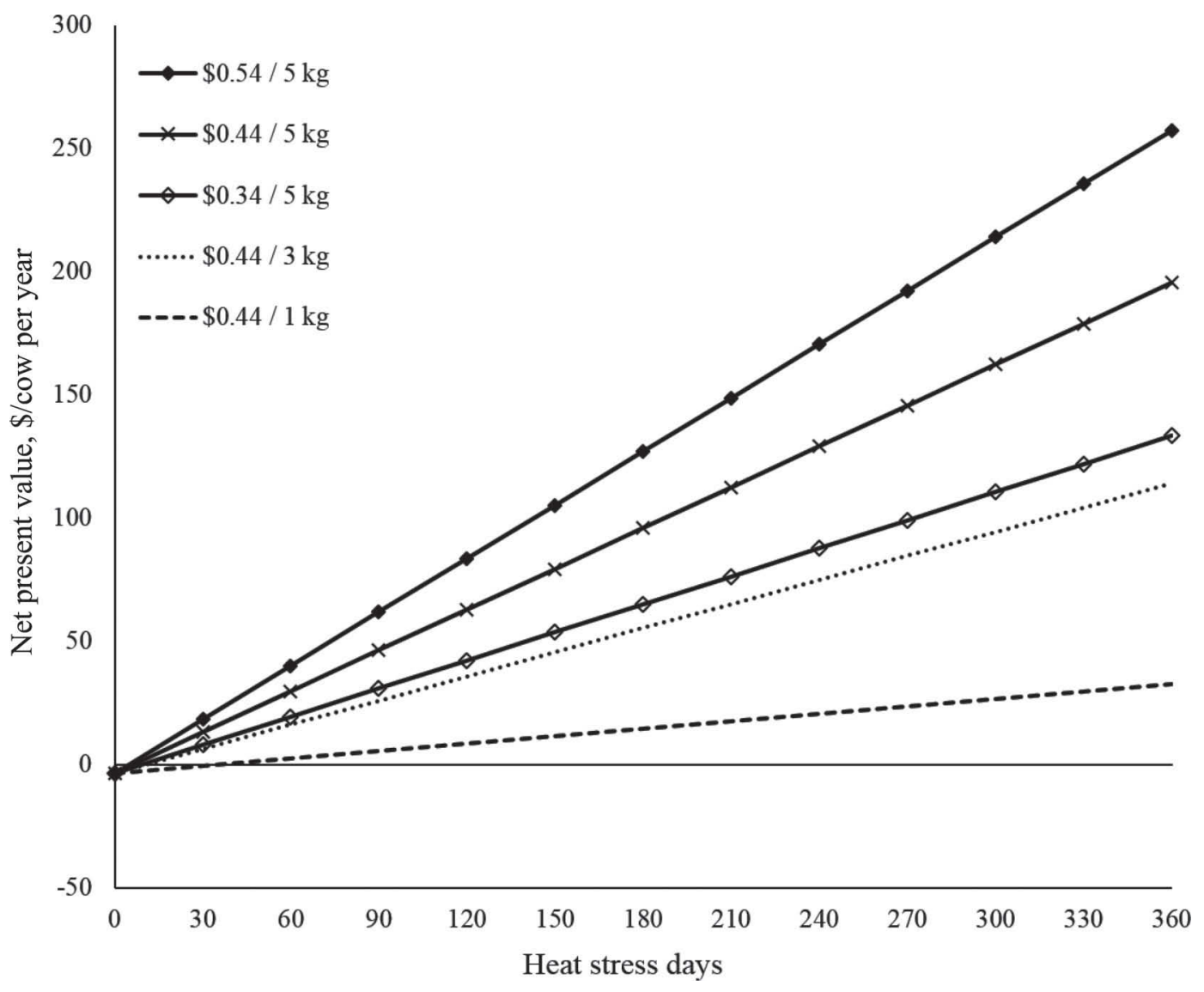

Figure 4. Net present value per cow per year for 0 to $360 \mathrm{~d}$ of heat stress per year. Only the costs of fans and soakers are included but not barn investment costs. Milk prices $(\$ / \mathrm{kg}): 0.34,0.44$, and 0.54 . Increase in milk yield $(\mathrm{kg} / \mathrm{d}): 1,3$, and 5 . 


\section{Investment Analysis}

Generally, cooling of dry cows was found to be very profitable. Adin et al. (2009) found a breakeven milk yield of $80 \mathrm{~kg}$ in the subsequent lactation in Israel to pay for cooling dry cows. Those authors did not include the increase in DMI, but included the investments in cooling facilities, installation, and operation costs. The number of heat stress days in their experiment was approximately $120 \mathrm{~d}$. When using our model with default prices and including the increase in DMI, our breakeven yield would be $265 \mathrm{~kg}$ of milk in each subsequent lactation to reach an NPV equal to $\$ 0$. At a response of $5 \mathrm{~kg} / \mathrm{d}$, this extra milk production is realized in $53 \mathrm{~d}$. If a barn is not necessary, the breakeven yield would be $40 \mathrm{~kg}$ of milk in each subsequent lactation.

\section{Other Effects of Heat Stress Not Included in This Study}

This study included effects of heat stress on only milk production in the subsequent lactation. We assumed that cows survived at least $340 \mathrm{~d}$ in the subsequent lactation. In practice, approximately 20 to $50 \%$ of cows are culled in the subsequent parity and would only benefit from cooling in the previous dry period until they are culled. On the other hand, other benefits of cooling dry cows were not included in our analysis. For example, replacement heifers might benefit from cooling during later stages of their gestation and consequently milk production in the first parity would increase. Another factor not included is that when a cooling barn is built, dry cows are moved from alternative housing to inside the cooling barn. This would reduce the costs of the alternative housing and further increase the value of investment in a barn with cooling.

Various other effects of heat stress during the dry period on animal performance have been documented or are being discovered. Heat stress during the dry period shortens gestation length (Collier et al., 1982; Tao and Dahl, 2013), which has been associated with a decrease in milk production in the beginning of the subsequent lactation (Bremmer et al., 1999). In addition, an increase in the number of stillbirths (A. Vieira-Neto, University of Florida, Gainesville, personal communication), and an increase in the incidence of postpartum diseases (Adin et al., 2009) is reported. The immune function was compromised in cows that underwent heat stress during the dry period (do Amaral et al., 2011). Milk fat might also decrease (Avendaño-Reyes et al., 2006; do Amaral et al., 2009). Cows dry in hot months had an increase in the number of days to first insemination, number of inseminations, increased culling for reproductive failure (Wiersma and Armstrong,
1988), and days to pregnancy diagnosis during the first 150 DIM in the subsequent lactation relative to those dry in cool months (Thompson and Dahl, 2012). Calves born from cows exposed to heat stress during their dry period had lower birth weights (Collier et al., 1982; do Amaral et al., 2011; Tao et al., 2012) and compromised passive immune transfer (Tao et al., 2012). Some evidence is emerging that fertility and milk production through the first lactation are negatively affected if the female experienced heat stress around the time of her creation (Brown et al., 2016) and at the end of gestations before she was born (Monteiro et al., 2016). The economic consequences from these effects are not easily evaluated. Therefore, the economic benefits from cooling dry cows in this study appear to be conservative.

\section{CONCLUSIONS}

The average US dairy cow (including first lactating cows) would experience 96 heat stress days during the year if not cooled and lose $290 \mathrm{~kg}$ of milk in the subsequent lactation if not cooled when dry. Annual losses would be $\$ 810$ million if dry cows were not cooled. Cooling of dry cows was profitable for $89 \%$ of the cows in United States when building a new barn is needed (under default assumptions) and very profitable when construction of a dry cow barn is not required (except for Alaska).

\section{ACKNOWLEDGMENTS}

Fernanda C. Ferreira thanks CAPES (Coordenação de Aperfeiçoamento de Pessoal de Nível Superior), Brazil, for the financial support of her graduate studies. This study was supported by the USDA-Agriculture and Food Research Institute (USDA/NIFA AFRI, Washington, DC) Foundational Program Award \#2015-67015-23409 to G. E. Dahl.

\section{REFERENCES}

Adin, G., A. Gelman, R. Solomon, I. Flamenbaum, M. Nikbachat, E. Yosef, A. Zenou, A. Shamay, Y. Feuermann, S. J. Mabjeesh, and J. Miron. 2009. Effects of cooling dry cows under heat load conditions on mammary gland enzymatic activity, intake of food water, and performance during the dry period and after parturition. Livest. Sci. 124:189-195. http://dx.doi.org/10.1016/j.livsci.2009.01.014.

al-Katanani, Y. M., D. W. Webb, and P. J. Hansen. 1999. Factors affecting seasonal variation in 90-day nonreturn rate to first service in lactating Holstein cows in a hot climate. J. Dairy Sci. 82:26112616. http://dx.doi.org/10.3168/jds.S0022-0302(99)75516-5.

Avendaño-Reyes, L., F. D. Alvarez-Valenzuela, A. Correa-Calderón, J. S. Saucedo-Quintero, P. H. Robinson, and J. G. Fadel. 2006. Effect of cooling Holstein cows during the dry period on postpartum performance under heat stress conditions. Livest. Sci. 105:198-206. http://dx.doi.org/10.1016/j.livsci.2006.06.009.

Baumgard, L. H., and R. P. Rhoads. 2012. Ruminant Nutrition Symposium: Ruminant production and metabolic response to heat stress. J. Anim. Sci. 90:1855-1865. 
Bremmer, D. R., J. O. Christensen, R. R. Grummer, F. E. Rasmussen, and M. C. Wiltbank. 1999. Effects of induced parturition and estradiol on feed intake, liver triglyceride concentration, and plasma metabolites of transition dairy cows. J. Dairy Sci. 82:1440-1448. http://dx.doi.org/10.3168/jds.S0022-0302(99)75371-3.

Brown, B. M., J. W. Stallings, J. S. Clay, and M. L. Rhoads. 2016. Periconceptional heat stress of Holstein dams is associated with differences in daughter milk production during their first lactation. PLoS One 11:e0148234 http://dx.doi.org/10.1371/journal. pone. 0148234

Collier, R. J., G. E. Dahl, and M. J. Van Baale. 2006. Major advances associated with environmental effects on dairy cattle. J. Dairy Sci. 89:1244-1253. http://dx.doi.org/10.3168/jds.S00220302(06)72193-2.

Collier, R. J., S. G. Doelger, H. H. Head, W. W. Thatcher, and C. J. Wilcox. 1982. Effects of heat stress during pregnancy on maternal hormone concentrations, calf birth weight and postpartum milk yield of Holstein cows. J. Anim. Sci. 54:309-319.

De Rensis, F., I. Garcia-Ispierto, and F. Lopez-Gatius. 2015. Seasonal heat stress: Clinical implications and hormone treatments for the fertility of dairy cows. Theriogenology 84:659-666. http://dx.doi. org/10.1016/j.theriogenology.2015.04.021.

De Vries, A., and C. A. Risco. 2005. Trends and seasonality of reproductive performance in Florida and Georgia dairy herds from 1976 to 2002. J. Dairy Sci. 88:3155-3165. http://dx.doi.org/10.3168/ jds.S0022-0302(05)72999-4.

Dhuyvetter, K. C., T. L. Kastens, M. J. Brouk, J. F. Smith, and J. P. Harner. 2000. Economics of cooling cows. Heart of America Dairy Management Conf., St. Joseph, MO.

do Amaral, B. C., E. E. Connor, S. Tao, J. Hayen, J. Bubolz, and G. E. Dahl. 2009. Heat stress abatement during the dry period: Does cooling improve transition into lactation? J. Dairy Sci. 92:59885999. http://dx.doi.org/10.3168/jds.2009-2343.

do Amaral, B. C., E. E. Connor, S. Tao, M. J. Hayen, J. W. Bubolz, and G. E. Dahl. 2011. Heat stress abatement during the dry period influences hepatic gene expression and improves immune status during the transition period of dairy cows. J. Dairy Sci. 94:86-96. http://dx.doi.org/10.3168/jds.2009-3004.

DOL (Department of Labor). 2015. U.S. Bureau of Labor Statistics. Accessed May 26, 2016. http://data.bls.gov/cgi-bin/cpicalc.pl?cos $\mathrm{t} 1=5.94 \&$ year $1=2000 \&$ year $2=2015$

Du, F. 2013. Characterization of pasture-based dairy farms in Florida and Georgia. MS Thesis. Univ. Florida, Gainesville. Accessed May 26, 2016. http://ufdc.ufl.edu/UFE0046020/00001

Gould, B. W. 2016. Understanding Dairy Markets. Milk Prices. Accessed May 26, 2016. http://future.aae.wisc.edu/data/annual_ values/by_area $/ 10$ ?tab $=$ prices

GRU (Gainesville Regional Utilities). 2016. Rates, Deposits and Fees. Accessed May 26, 2016. https://www.gru.com/Portals/0/Legacy/ Pdf/FY16\%20Rate\%20Sheets/Rates\%20FY16\%20Non\%20 Residential\%20V4.pdf

Higgins, R. C. 2001. Analysis for Financial Management. 6th ed. McGraw-Hill Higher Educ., New York, NY.

Igono, M. O., G. Bjotvedt, and H. T. Sanford-Crane. 1992. Environmental profile and critical temperature effects on milk production of Holstein cows in desert climate. Int. J. Biometeorol. 36:77-87.

IRS (Internal Revenue Service). 2016. Depreciation, Depletion, and Amortization. Accessed Jan. 6, 2016. https://www.irs.gov/ publications/p225/ch07.html.

Jordan, E. R. 2003. Effects of heat stress on reproduction. J. Dairy Sci. 86(E. Suppl.):E104-E114. http://dx.doi.org/10.3168/jds.S00220302(03)74043-0.

Kadzere, C. T., M. R. Murphy, N. Silanikove, and E. Maltz. 2002 Heat stress in lactating dairy cows: A review. Livest. Prod. Sci. 77:59-91. http://dx.doi.org/10.1016/S0301-6226(01)00330-X.

Kammel, D. W. 2015. Building Costs Estimates - Dairy Modernization. Univ. Wisconsin. Accessed May 26, 2016. http:// fyi.uwex.edu/dairy/files/2015/11/Building-Cost-Estimates-DairyModernization.pdf.

Monteiro, A. P., S. Tao, I. M. T. Thompson, and G. E. Dahl. 2016. In utero heat stress decreases calf survival and performance through the first lactation. J. Dairy Sci. 99:8443-8450. http://dx.doi org/10.3168/jds.2016-11072.

NRC. 2001. Nutrient Requirements of Dairy Cattle. 7th rev. ed. Natl. Acad. Press, Washington, DC.

NOAA (National Oceanic and Atmospheric Administration). 2015. National Centers for Environmental Information. Accessed May 26, 2016. http://www.ncdc.noaa.gov/.

Oseni, S., I. Misztal, S. Tsuruta, and R. Rekaya. 2003. Seasonality of days open in US Holsteins. J. Dairy Sci. 86:3718-3725. http:// dx.doi.org/10.3168/jds.S0022-0302(03)73977-0.

Rollin, E.. K. C. Dhuyvetter, and M. W. Overton. 2015. The cost of clinical mastitis in the first 30 days of lactation: An economic modeling tool. Prev. Vet. Med. 122:257-264. http://dx.doi. org/10.1016/j.prevetmed.2015.11.006.

Scott, I. M., H. D. Johnson, and G. L. Hahn. 1983. Effect of programmed diurnal temperatures cycles based on plasma thyroxine level, body temperature, and feed intake of Holstein dairy cows. Int. J. Biometeorol. 27:47-62.

St-Pierre, N. R., B. Cobanov, and G. Schnitkey. 2003. Economic losses from heat stress by US livestock industries. J. Dairy Sci. 86(E. Suppl.):E52-E77. http://dx.doi.org/10.3168/jds.S00220302(03)74040-5

Tao, S., J. W. Bubolz, B. C. do Amaral, I. M. Thompson, M. J. Hayen, S. E. Johnson, and G. E. Dahl. 2011. Effect of heat stress during the dry period on mammary gland development. J. Dairy Sci. 94:5976-5986. http://dx.doi.org/10.3168/jds.2011-4329.

Tao, S., and G. E. Dahl. 2013. Invited review: Heat stress impacts during late gestation on dry cows and their calves. J. Dairy Sci. 96:4079-4093. http://dx.doi.org/10.3168/jds.2012-6278.

Tao, S., I. M. Thompson, A. P. A. Monteiro, M. J. Hayen, L. J. Young, and G. E. Dahl. 2012. Effect of cooling heat-stressed dairy cows during the dry period on insulin response. J. Dairy Sci. 95:50355046. http://dx.doi.org/10.3168/jds.2012-5405.

Thatcher, W. W., L. Badinga, R. J. Collier, H. H. Head, and C. J. Wilcox. 1984. Thermal stress effects on the bovine conceptus: Early and late pregnancy. In Reproduction Des Ruminants En Zone Tropicale. Les Colloques de I'TNRA. INRA Publ. No. 20:265-284.

Thompson, I. M., and G. E. Dahl. 2012. Dry-period seasonal effects on the subsequent lactation. Prof. Anim. Sci. 28:628-631. http:// dx.doi.org/10.15232/S1080-7446(15)30421-6.

Thompson, I. M. T., S. Tao, A. P. A. Monteiro, K. C. Jeong, and G. E. Dahl. 2014. Effect of cooling during the dry period on immune response after Streptococcus uberis intramammary infection challenge of dairy cows. J. Dairy Sci. 97:7426-7436. http://dx.doi. org/10.3168/jds.2013-7621.

Urdaz, J. H., M. W. Overton, D. A. Moore, and J. E. P. Santos. 2006. Technical note: Effects of adding shade and fans to a feedbunk sprinkler system for preparturient cows on health and performance. J. Dairy Sci. 89:2000-2006. http://dx.doi.org/10.3168/ jds.S0022-0302(06)72267-6.

USDA-NASS. 2016. Milk Production Report. Accessed May 26, 2016. http://future.aae.wisc.edu/data/monthly_values/by_ area $/ 3712$ ?area $=$ US

West, J. W. 2003. Effects of heat-stress on production in dairy cattle. J. Dairy Sci. 86:2131-2144. http://dx.doi.org/10.3168/jds.S00220302(03) 73803-X.

Wiersma, F., and D. V. Armstrong. 1988. Evaporative cooling dry cows for improved performance. ASAE paper no. 88-4053, St. Joseph, MI.

Wolfenson, D., I. Flamembaum, and A. Berman. 1988. Dry period heat stress relief effects on prepartum progesterone, calf birth weight, and milk production. J. Dairy Sci. 71:809-818. http:// dx.doi.org/10.3168/jds.S0022-0302(88)79621-6.

Zimbelman, R. B., R. P. Rhoads, M. L. Rhoads, G. C. Duff, L. H Baumgard, and R. J. Collier. 2009. A re-evaluation of the impact of temperature humidity index (THI) and black globe humidity index (BGHI) on milk production in high producing dairy cows. Pages 158-168 in Proc. Southwest Nutr. Man. Conf., Tempe, AZ. Univ. Arizona, Tucson. 